\title{
A NEW VIEW ON THE QUALITY OF JACÍK’S TEST
}

\author{
Roman Cuberek, Aleš Jakubec, Karel Hůlka, Michal Botek
}

Faculty of Physical Culture, Palacký University, Olomouc, Czech Republic

Submitted in July, 2011

BACKGROUND: A self-assessment of physical fitness requires a search for motor tests which do not make high material, spatial and skill demands necessary for tests' realization. In this manner, Jacík's test (JT) appears to be an appropriate one. Nevertheless, existing information about the test quality is not complete. Based on the motion content of this test, the test performance can be considered to be determined by the level of aerobic fitness.

OBJECTIVE: The aim of this study is to assess the reliability of JT and to determine degree of influence of aerobic fitness on JT performance.

METHODS: Eighty four PE university students completed the study - 43 female (participated in the validity study; $22.2 \pm 2.0$ year; $\mathrm{BMI}=23.2 \pm 2.5 \mathrm{~kg} / \mathrm{m}^{2} ; \mathrm{JT}$ performance $=79.1 \pm 9.2$ points; $\mathrm{VO}_{2} \max =44.6 \pm 4.7 \mathrm{ml} / \mathrm{kg} / \mathrm{min}$. $)$ and 41 males (participated in the reliability study; $21.5 \pm 1.2$ year; BMI $=25.2 \pm 1.6 \mathrm{~kg} / \mathrm{m}^{2}$; JT performance $=83.9 \pm 8.2 \mathrm{points}$ in the first trial and $87.5 \pm 9.1$ points in the second trial respectively). The degree of influence of aerobic fitness on the performance in JT is expressed as association between the performance in $\mathrm{JT}$ and $\mathrm{VO}_{2}$ max estimation (measured by Maximal exercise test realized on a treadmill). The objectivity and the relative reliability of JT are expressed by ICC. Characteristics SEM and Bland-Altman's 95\% limits of agreement were computed to assess absolute reliability of JT.

RESULTS: A little of shared variability of $\mathrm{JT}$ and $\mathrm{VO}_{2}$ max respectively was found out (only $13.3 \%$ ). $\mathrm{ICC}_{\text {inter-raters }}=$ 0.997 indicates a high degree of objectivity (inter-rater reliability). The result of $\mathrm{ICC}_{\text {inter-trials }}=0.790$ points to a "questionable" relative reliability. The systematic error of measurement equals to 3.54 points. Both SEM (3.96 points) and Bland-Altman's $95 \%$ limits of agreement $(-9.2,16.3)$ point out to the unsatisfactory degree of absolute reliability.

CONCLUSION: Mainly due to the low degree of the test's reliability (both relative and absolute), JT is not an accurate tool for assessing physical fitness in PE university students. The interpretation of testing results could be misleading.

Keywords: Motor tests, PE students, reliability, self-assessment, validity, $\mathrm{VO}_{2}$ max.

\section{INTRODUCTION}

Assessment of physical fitness has gone through a long development as well as the changed assessment approach connected with its conception and definition. With respect to close relationship between fitness and health (Heyward, 2010; Janssen \& LeBlanc, 2010; Suchomel, 2004; Vanhees et al., 2005), it seems to be appropriate to divide the term "fitness" into two categories - health-related and performance-related. As Vanhees et al. (2005) claims, health-related fitness is then viewed as a state characterized by an ability to perform daily activities with vigour, and traits and capacities that are associated with low risk of premature development of the hypokinetic diseases (i.e., those associated with physical inactivity). Today's conception of fitness assessment has deviated from predominantly performancerelated fitness towards the health-related one, which also resulted in reduction of test items within the established test batteries (Suchomel, 2003). According to Plowman et al. (2006), FITNESSGRAM, whose the last ninth version reflects its long lasting development, belongs amongst the most elaborated fitness test batteries. In a sense of increasing quality of particular tests and the whole test battery (its validity and reliability), many tests have been removed or modified in the course of development (Welk \& Meredith, 2008). Since 2009 a research group from the Centre for Kinanthropology Research (Faculty of Physical Culture, Palacký University in Olomouc) has been working on a conception named "Self-assessment of physical fitness" and forms an appropriate web-based system of motor tests (software INDARES.com). Although some of the attributes of this conception can be presently found in the last version of the FITNESSGRAM system (strong involvement of an individual into the test realization; on-line data recording in special software accessible on internet), this diagnostic approach to assessment of physical fitness is completely new (Welk \& Meredith, 2008). The basic assumption for the self-assessment conception is a positive effect (Marcus \& Forsyth, 2009) of a strategy called "self-orientation of an individual" (interiorization) within physical activity behavioural changes. The physical fitness self-assessment is somewhat limited 
when compared with "classic" health-related fitness assessment. These limits are mainly presented by material, spatial and knowledge-based demands corresponding with specific test realization. Therefore, many current tests are insufficient for this purpose (some appropriate alternative of the test is necessary) or the tests need to be somewhat modified.

Aerobic fitness, as a part of five item model of health-related fitness (body composition, cardiovascular capacity, flexibility, muscular endurance, and muscle strength), is amongst the most important parts because of its high association with the risk of cardiovascular diseases. According to WHO (2010), physical inactivity, that directly results in the level of aerobic fitness, is an independent risk factor of chronic diseases, and annually causes death of about 1,9 million people in the whole world.

The maximum oxygen consumption $\left(\mathrm{VO}_{2} \max \right)$ is commonly used as a suitable indicator to assess aerobic fitness (Caspersen, Powell, \& Christenson, 1985; Heyward, 2010; Mahar, Welk, Rowe, Crotts, \& McIver, 2006; The President's Council on Physical Fitness and Sports, 2010; Vanhees et al., 2005). Due the fact, that the most precise estimate of this parameter requires laboratory conditions, this indicator of aerobic fitness is hardly acceptable for field use. To obtain at least rough estimate of this parameter many field performance tests (Continuous to exhaustion tests, Intermittent tests, and Walking/running tests) or simple intensity tests (any of the group from step tests) are used by many test systems. Nevertheless, the accuracy of these estimates vary a lot it depends on the type of the test and/or other factors such as "age", "gender" etc. (e.g. in meta-analytical study Baumgartner and Jackson (1982) presented the level of criterion validity of long distance running tests - criterion $\mathrm{VO}_{2} \mathrm{max}$ - that ranges from 0.22 to 0.91 ).

In 1983 V. Jacík published his results regarding to a new formed field performance test named "Overall motor test” (orig. "Celostní motorický test”) (Jacík, 1983) (at present called "Jacík's test” and here abbreviated "JT") including characteristics of test's quality such as validity and reliability and norms for both boys and girls aged from 7 to 20 years. The test forming relates to two principles - human ontogenetic development and global understanding of human kinetics. The changes of elementary positions (reaching the vertical body position mainly) that are included in the test, the author considered to be one of the culminations of child's kinetic ontogeny necessary for his/her following development. At once, they are usually included into the group of activities forming the base of humans' movement base. In author's mind the test execution doesn't need any special skills. As a matter of this fact, an influence of cultural-social, racial, and geographical difference is, within the age group or gender, reduced. As the author claims, however the test result is conditioned by a complex of several skills (hybrid base), global endurance dominates. While forming the test, the author proved concurrent validity concerning to the two criteria. The first criterion was "The badge of fitness" named BBPOV ("Bud" připraven $\mathrm{k}$ práci a obraně vlasti”) where the level of validity were expressed by the correlation coefficient $r=0.483$ to 0.537 and the second criterion was "Test of basic physical fitness for university students" where $r=0.642$ (females) and $r=0.780$ (males). The author considers the test to be "satisfactory valid" indicator of the overall physical fitness.

In spite of the fact that JT is frequently used in a practice (e.g. as a particular item of an entrance exam to secondary schools or universities) no study clarifying participation of particular motor abilities that influence the overall performance in JT has been produced yet. In consideration of criterion choice (The badge of fitness BPPOV), we do not agree with Jacík's choice to determine test validity as indicator of the construct "overall physical fitness", and we consider this determination to be inappropriate. Due to a wide content of "The badge of fitness BPPOV" it is highly difficult to explain the results of JT with such a poor validity. Another weak point of the test standardization by Jacík is the presented results and their reliability. The results cannot be taken as sufficient for methods of their calculation that are not sensitive to numbers of measurement errors.

When looking for appropriate field test of selfassessment of aerobic fitness, a lot of obstacles appear. Though some weaknesses of JT, from the material and spatial demands, such a test seems to be an adequate test useful for self-assessment of physical fitness (in general). Moreover, because of dominance of global endurance in performance of JT, as mentioned above, one can expect high association between the test performance and the level of aerobic fitness of individual. Considering all these circumstances, there is a high chance that the test is suitable for aerobic fitness self-assessment. By this means, a research problem can be specified as verifying JT as suitable test for aerobic fitness assessment.

The aim of this study is to assess the Jacík's test reliability and to specify participation of aerobic fitness on the test performance (to assess criterion validity of the test as an indicator of aerobic fitness).

\section{METHODS}

\section{Participants}

Eighty nine PE university students participated in the study. The selection of participants was partly limited because of realization of the study was linked to teaching process of PE students (an interconnection of the faculty research and the teaching process). 
In this sense, it was necessary divide the study into the two parts - "sex-divided" sample (validity study 44 females; reliability study - 45 males). In the course of the study five students did not complete all measurements (personal reasons, illness). Complete data were obtained from 43 females $(22.2 \pm 2.0$ year, $\mathrm{BMI}=23.2$ $\left.\pm 2.5 \mathrm{~kg} / \mathrm{m}^{2}\right)$ and 41 males $(21.5 \pm 1.2$ year, $\mathrm{BMI}=25.2$ $\left.\pm 1.6 \mathrm{~kg} / \mathrm{m}^{2}\right)$.

The Institutional research ethics committee of Faculty of Physical Culture of Palacký University agreed to the proposed research and approved the study with no. 7/2011. The students were informed about the intention of the study and all procedures. A demand to obtain the relatively maximal possible performance was emphasized. All participants took part in this study voluntarily, after being properly informed. They were asked to participate during their PE classes and their decision to participate did not have any negative effects on their studies.

\section{Measures and procedures}

All measurements were realized at the Faculty of Physical Culture at Palacký University in Olomouc (Czech Republic) from October 2010 to February 2011. The basic somatic characteristics such as weight and height were measured in order to determine BMI. All students took part in JT and in a partial study to assess the validity, each of them had to undergo physiological load test to define $\mathrm{VO}_{2}$ max on a treadmill.

Maximal exercise test. The investigations were carried out under relatively standard conditions (temperature $19-21{ }^{\circ} \mathrm{C}$, humidity $40-50 \%$ ) in the laboratory of the Faculty of Physical Culture. The participants were asked to come with an empty stomach and to abstain from drinking coffee, alcohol and hard physical activities for 24 hours before entering the laboratory.

Graded exercise test till maximum was realized on a LODE Valiant treadmill (Netherland). Heart rate and spiroergometric variables were monitored during the test. After five minutes of warming-up at walking speed $7 \mathrm{~km} /$ hour (at last minute treadmill slope was increased up to $5 \%$ ) treadmill speed was for one minute increased to $9 \mathrm{~km} /$ hour. Subsequently, each 30 seconds speed increased about $1 \mathrm{~km} /$ hour up to $12 \mathrm{~km} /$ hour. After achievement of this speed, each 30 seconds treadmill slope was increased about $2 \%$ up to subject's volitional maximum. Oxygen consumption among the others spiroergometric parameters was monitored with use of breath-by-breath gas analyzer (ZAN Ergo USB 600, Germany). Simultaneously, a Polar (Finland) heart rate monitor was applied. We considered only one essential parameter from all the monitored parameters - maximum oxygen consumption - $\mathrm{VO}_{2} \max [\mathrm{ml} / \mathrm{kg} / \mathrm{min}$.]
Jacík's test (JT). To assess the validity of JT, females performed the test once (after one week from performing Maximal exercise test); to assess reliability, men performed the test twice (one week pause from the first test actualization). The first test performance was monitored by one observer, whereas the second (males) measurement was monitored by two observers (to assess objectivity). The test was always performed under the same conditions (on a pad) based on exactly set assignment (Jacík, 1983) - to change repetitively three positions during two minutes (back-lying position is a starting one; followed by heel-stand, abdomen-lying position, heel-stand, back-lying position etc.); each position is finished by clapping palms to thighs and the result of this test is a number of performed positions numbered as points. The individual is informed about the last ten remaining seconds.

\section{Statistical analysis}

Software SPSS 17 (SPSS Inc., Chicago, IL) and Statistica 8 (StatSoft Inc., Tulsa, OK) were used to process the data. Basic descriptive characteristics such as mean, standard deviation and 95\% confidence intervals were calculated for all the indicators. After verifying normality assumption, while assessing a) criterion validity of JT, b) describing the relationship between JT and BMI, c) and verifying homoscedasticity of JT (relationship between variables - 1. absolute value of difference of repeated individual performance and 2. average value of repeated individual performance), a coefficient of Pearson product moment correlation completed with the value of coefficient of determination (as effect size) was used. The objectivity of JT (two observers; probed at the second attempt), as one of the sources of measurement errors and the level of relative reliability, expressed through intra-class correlation (ICC, parallel one-way model), was calculated according to formula $\mathrm{ICC}=\left(\mathrm{MS}_{\mathrm{S}}-\mathrm{MS}_{\mathrm{E}}\right) / \mathrm{MS}_{\mathrm{S}}$, where $\mathrm{MS}_{\mathrm{S}}=$ "mean square of subjects", $\mathrm{MS}_{\mathrm{E}}=$ "mean square of error". Standard error of measurement (SEM), and Bland and Altman's 95\% limits of agreement were computed to estimate absolute reliability of JT. Then, these limits were graphically depicted by Bland and Altman's plot (according to Atkinson \& Nevill, 1998). SEM was calculated by a formula according to the methods of Thomas, Nelson,

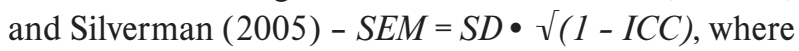
$S E M=$ "standard error of measurement", $S D=$ the sample standard deviation and $I C C=$ the calculated intraclass correlation coefficient (unbiased error). Microsoft Excel was used to construct Bland and Altman's plot.

Paired $t$-test for repeated measures (null hypothesis about equal means in the two repeated performances in JT was verified; 5\% level of statistical significance) and the value of effect size (ES; Cohen's $d$ coefficient 
for repeated measures calculated according to Cohen (1988)) were used to assess systematic bias in JT.

\section{RESULTS}

Results in TABLE 1 involve basic indicators of somatic and performance characteristics in the research sample. They are divided into the two groups in accordance with two parts of research - the validity study (females) and the reliability study (males). The somatic indicator is represented with BMI; the motor indicator is represented with aerobic fitness $\left(\mathrm{VO}_{2} \mathrm{max}\right)$ and performance in JT. The observed BMI in females, WHO (2010) interprets as a normal weight, resp. immediately above the lower limit of overweight category in males. Considering this interpretation should be advised well-known limitation of usage of BMI in individuals having the above average developed musculature. Given the nature of the sample, this limitation must be respected when interpreting observed BMI. According to Jacík’s (Jacík, 1983) five-scale population norm (in age category 19-20 year), it is possible to assess the performance reached by females as "above average" and by males as performance as "average”. According to the Czech female's norm of oxygen uptake at maximal load (Seliger \& Bartůněk, 1978) (although it is outdated there are not recent norms in the Czech Republic) sample of the observed females can be interpreted as strongly above average.

The part A in the TABLE 2 describes the relationship between performance in JT and the level of aerobic fitness criterion $\left(\mathrm{VO}_{2} \mathrm{max}\right)$ completed with the relationship of the variables towards the somatic indicator BMI. The coefficient of determination $\left(r^{2}\right)$ indicates that proportion of shared variability in $\mathrm{JT}$ and $\mathrm{VO}_{2} \mathrm{max}$ is very low $-13.3 \%$ only. With reference to calculated correlation, neither BMI is a factor significantly determining their performance in JT. The value of Pearson's correlation coefficient (the coefficient of determination respectively; TABLE 2, section B) between the absolute values of difference and the average value of repeated individual performances in JT (a week interval) indicates

\section{TABLE 1}

Sample characteristics

\begin{tabular}{|l|c|c|c|}
\hline Indicator & M & SD & 95\% CI \\
\hline Females $(\mathrm{n}=43)($ validity study) & & & $(22.5,24.0)$ \\
\hline Body Mass Index $\left(\mathrm{kg} \bullet \mathrm{m}^{2}\right)$ & 23.2 & 2.5 & $(76.2,81.9)$ \\
\hline Jacík's test $($ the number of positions $)$ & 79.1 & 9.2 & $(45.7,51.0)$ \\
\hline $\mathrm{VO}_{2} \mathrm{max}(\mathrm{ml} / \mathrm{kg} / \mathrm{min})$. & 44.6 & 4.7 & $(24.2,26.2)$ \\
\hline Males $(\mathrm{n}=41)($ reliability study) & & 1.6 & $(81.3,86.5)$ \\
\hline Body Mass Index $\left(\mathrm{kg} \cdot \mathrm{m}^{2}\right)$ & 25.2 & 8.2 & $(84.6,90.3)$ \\
\hline Jacík's test* the number of positions $)$ & 83.9 & 9.1 & \\
\hline Jacík's test** the number of positions $)$ & 87.5 & & \\
\hline
\end{tabular}

Legend: M - mean, SD - standard deviation, 95\% CI - 95\% confidence interval, * - the first trial, ** - the second trial

TABLE 2

Validity and reliability characteristics of Jacík's test - Pearson correlation coefficient $(r)$ and intraclass correlation (ICC)

\begin{tabular}{|c|c|c|c|}
\hline Pairs of variable & $r$ & $r^{2}$ & $\operatorname{ICC}(95 \% C I)$ \\
\hline \multicolumn{4}{|l|}{ A) Validity study (females, $n=43$ ) } \\
\hline Jacík's test vs. $\mathrm{VO}_{2} \max$ & 0.365 & 0.133 & - \\
\hline Jacík’s test vs. BMI & -0.093 & 0.009 & - \\
\hline $\mathrm{VO}_{2} \max$ vs. BMI & 0.280 & 0.078 & - \\
\hline \multicolumn{4}{|l|}{ B) Reliability study (males, $n=41$ ) } \\
\hline Jacík’s test (Diff ${ }_{\text {retest }}$ vs. Mean ${ }_{\text {retest }}$ ) & 0.143 & 0.021 & - \\
\hline Jacík's test (Observer 1 vs. Observer 2) & - & - & $0.997(0.995,0.999)$ \\
\hline Jacík’s test (Week 1 vs. Week 2) & - & - & $0.790(0.607,0.888)$ \\
\hline
\end{tabular}

Legend: Diff retest $^{-}$absolute value of difference between repeated measurement of individual performances in Jacík's test in one week

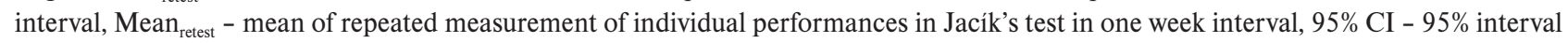
of confidence 
the data homoscedasticity (the error of measurement does not grow with increasing score in JT). Therefore, it is not necessary to log-transformation of the obtained data. Calculated high value of intra-class correlation ICC (TABLE 2, section B, the relation "Jacík's test Observer 1" vs. “Jacík's test Observer 2") refers to a high level of objectivity, i.e. measurement is independent from the observer. The detected value of intra-class correlation for repeated measurements (TABLE 2, section B, the relation "Jacík's test Week 1" vs. "Jacík's test Week 2"), as an indicator of relative reliability, can be according to Atkinson et al. (1998) interpreted as a "questionable reliability".

The paired $t$-test proved statistical significance of the difference in reached points in JT between the first and second measurement (increase of 3.54 points, $t=3.484$, $p=0.001$ ), therefore, a null hypothesis was rejected. The variability of intra-individual performance differences highly varied (from - 10 to 31 points) - standard deviation of the increasing performance is 6.5 points. The value of Cohen's $d$ is equal to 0.41 and relates to a medium effect of a factor which causes the intra-individual performance differences in the test (Cohen, 1988). Here, the measured difference ( 3.54 points) represents a bias of measurement.

The absolute reliability is expressed by the standard error of measurement (SEM). In male participants the SEM value equals 3.96 points. The second indicator of the absolute reliability, Bland's and Altman's 95\% limits of agreement of repeated measurements, is graphically depicted in Fig. 1. The bias is presented with dotted line in the graph (the value equals to 3.54 points) together with $95 \%$ limits of agreement depicted with dashed lines (also $95 \%$ prediction interval) (see $+/-1.96 \mathrm{SD}$ in the graph), whose lower bound equals to -9.2 points and upper equals to 16.3 points.

\section{DISCUSSION}

The research sample included individuals with relatively consistent performance proved in JT (TABLE 1) (variation coefficient for females equals to $11.6 \%$; $9.8 \%$ for males in the first measurement and $10.4 \%$ in the second, respectively), whose performance can be classified, based on the general population norm, as above average in females, respectively average in males. These performance levels are expected in PE students because of their above average amount as well as intensity of realized daily physical activity (their study programme include a large number of physical activities during the week). Because of this homogeneity, the calculated correlation coefficients can be higher than those reached by the general population. It can be deducted that the indicators of reliability or validity expressed by these coefficients are even lower among the general population.

The degree of correlation between performances in $\mathrm{JT}$ and selected criterion of $\mathrm{VO}_{2}$ max indicates that

Fig. 1

A Bland-Altman plot for repeated measurement of Jacík's test. The differences between the trials are plotted against each individual's mean for the two trials in Jacík's test. The bias line and random error lines (+1.96SD and -1.96SD) forming the $95 \%$ limits of agreement are also presented in the plot

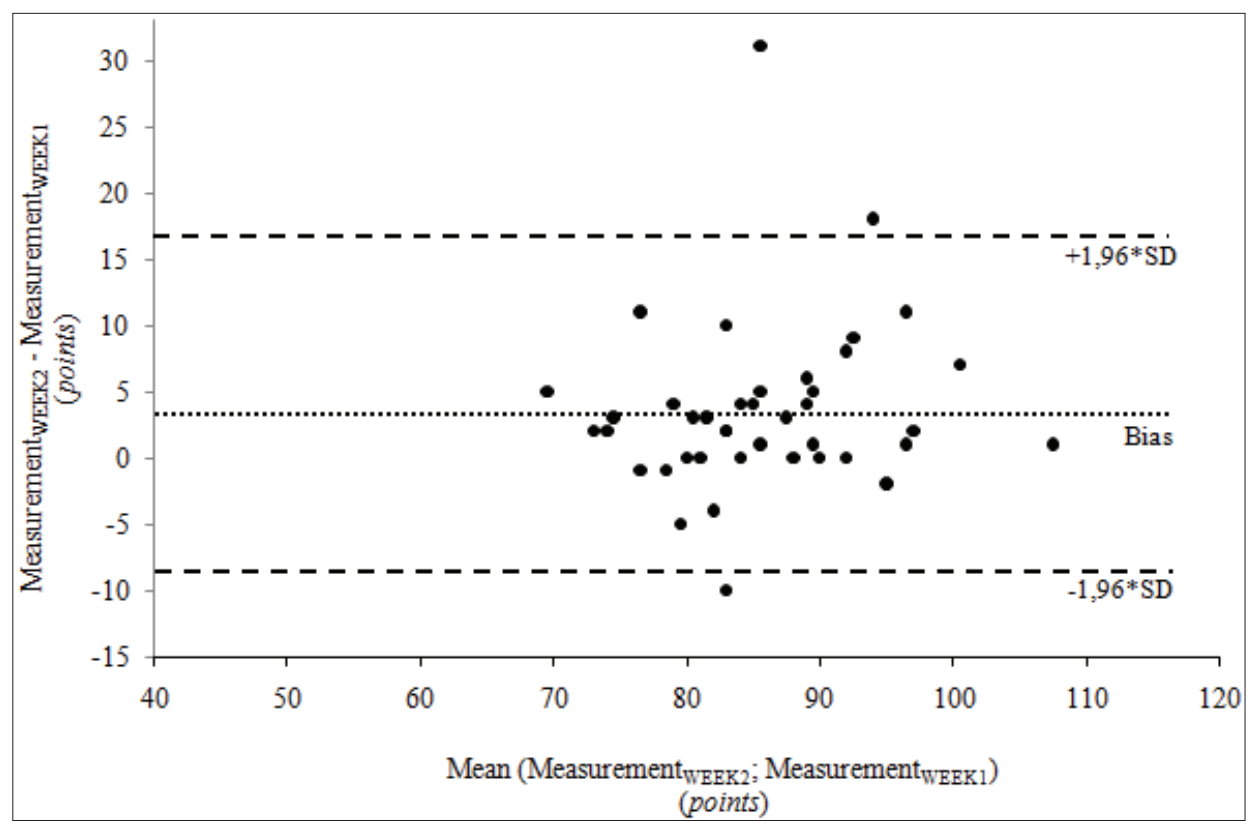


the validity of JT as an indicator for aerobic fitness is not satisfactory. Considering $\mathrm{VO}_{2} \mathrm{max}$ as an indicator of aerobic fitness, it must be claimed that this motor performance presumption influences only $13.3 \%$ of overall result in JT in female PE students. For example, in step-tests (depending on type of a test and population sample) it was found out this influence from 16\% (Canadian Home Fitness Test) up to 56\% (Queen College Step Test).

Actually, the probably best known running tests of aerobic fitness present still higher values (20 m Shuttle Run Test - 58\%; Cooper's 12 m Run - 81\%). However, as other results suggest, the low test validity level could be explained by the lower level of JT reliability.

Although the test objectivity seems to be highly satisfactory ( $\mathrm{ICC}=0.997$ ) in male PE students, other items of reliability analysis do not achieve such good results. The study showed that the test performance between two repeated attempts within a week interval increased on average by 3.54 points (systematic error) in male PE students. Only $14 \%$ of the cases were lower than in the previous attempt, and the variability of the re-test differences was high (from -10 to 31 points). The computed value of Cohen's $d$ (effect size) refers to a medium effect of a factor causing these changes. In the sense of high demands for accuracy of the test, we consider this value of systematic error to be practically significant. It can be estimated only, whether its source is the learning effect and experience with the test (most of the participants did this test for the first time) or not. The better participants learn, the better they can distribute their strength into the time limit of 2 minutes; a strategy they can use to increase or decrease rhythm of repeated positions within the attempt. In case learning effect affects the intra-individual differences, the re-test differences should decrease with number of attempts. The value of re-test's ICC (TABLE 2) and the range of its $95 \%$ interval of confidence points out a "questionable" relative reliability (Atkinson \& Nevill, 1998). It indicates very "unsteady" order of individual within the group in repeated testing and consequently its "unsteadiness" towards all normative results. We do not expect the interval between the test realizations had a significant impact on increasing or decreasing of individual's performance abilities for this test which would also be a possible source of measurement errors. In the case of this test, other sources of measurement errors might be tiredness, changes of health or change of motivation. The measurement was realized at the same time in one week period, and therefore we expect the contingent tiredness to be for all athletes (regular training) in both measurements the same or roughly the same.

In monitored males, the standard error of measurement in JT was 3.96 points which equals to $17.8 \%$ of one category of population norm compiled by Jacík. We consider this value to be practically significant. Computed Bland's and Altman's 95\% limits of agreement of repeated measurements (Fig. 1) reflects the fact that $98 \%$ of possible following test/re-test differences could range from -9.2 to 16.3 points (i.e. 25.5 points!). The magnitude of this interval (together with SEM value) denotes the low level of JT absolute reliability.

While test qualities were originally verified by Jacík, the reliability was assessed on the bases of correlation analysis only - the indicators of relative reliability respectively. Computed coefficients of stability $(r=0.854-0.875)$, long term stability $(r=0.807)$ and objectivity $(\mathrm{r}=0.981)$ led him to claim test reliability as satisfactory (Jacík, 1983). However, these results cannot be considered as sufficient, because the statistics used here (test/re-test correlation coefficient as stability and inter-rater correlation coefficient as objectivity) are not sensitive to many of measurement errors (e.g. mentioned standard error of measurement) (Atkinson \& Nevill, 1998; Hopkins, 2000; Thomas, Nelson, \& Silverman, 2005). The source of errors such as the already mentioned learning effect cannot be detected in coefficients computed by Jacík. Contrary to Jacík's results, based on our results in PE students we can confirm neither our assumption of sufficient test reliability nor of the test validity.

Limitations. In this study, it is necessary to point out to several limitations in the research - 1. although all the participants were PE university students (same university), the reliability and validity were verified separately in different groups of individuals (different gender); 2. the detected higher homogeneity of the research sample (lower data variability) could increase the level of Pearson's correlation coefficient used in the test; 3. the test/re-test differences in JT, just like in most motor tests, depend on a level of performance motivation of participants in partial trials - so the performance motivation can be considered as source of measurement error (in the study, this limitation was partly eliminated by clarifying the importance of an achievement of maximal performance in both trials to the participants).

\section{CONCLUSIONS}

The study showed considerably poor reliability (absolute and relative) of JT in PE university students. Therefore, the test is not an appropriate tool for assessing PE students' motor abilities, not even aerobic fitness. The results have showed that the performance in JT can be explained with $13 \%$ of $\mathrm{VO}_{2}$ max level - this is highly insufficient for aerobic fitness assessment. Due to the fact that the performance interpretation in this test might have been highly misleading, we do not con- 
sider the test to be used appropriately for any assessment purpose, unless the movement content of the test is changed or modified respectively (to increase test reliability).

\section{ACKNOWLEDMENT}

The study has been supported by the research grant from the Ministry of Education, Youth and Sports of the Czech Republic (No. MSM 6198959221) "Physical Activity and Inactivity of the Inhabitants of the Czech Republic in the Context of Behavioral Changes”.

\section{REFERENCES}

Atkinson, G., \& Nevill, A. M. (1998). Statistical methods for assessing measurement error (reliability) in variables relevant to sports medicine. Sports Medicine, 26(4), 217-238.

Baumgartner, T. A., \& Jackson, A. S. (1982). Measurement for evaluation in physical education (2 ed.). Boston: McGraw-Hill.

Caspersen, C. J., Powell, K. E., \& Christenson, G. M. (1985). Physical activity, exercise, and physical fitness: Definitions and distinctions for health-related research. Public Health Reports, 100(2), 126-131.

Cohen, J. (1988). Statistical power analysis for behavioral science (2nd ed.). Hillsdale, IL: Erlbaum.

Heyward, V. H. (2010). Advanced fitness assessment and exercise prescription ( 6 ed.). Champaign, IL: Human Kinetics.

Hopkins, W. G. (2000). Measures of reliability in sports medicine and science. Sports Medicine, 30(1), 1-15.

Jacík, V. (1983). Celostní motorický test. Tělesná výchova mládeže, 50(1), 245-258.

Janssen, I., \& LeBlanc, A. G. (2010). Systematic review of the health benefits of physical activity and fitness in school-aged children and youth. International Journal of Behavioral Nutrition and Physical Activity, 7, 40-55.

Mahar, M. T., Welk, G. J., Rowe, D. A., Crotts, D. J., \& McIver, K. L. (2006). Development and validation of a regression model to estimate $\mathrm{VO}_{2}$ peak from PACER $20 \mathrm{~m}$ shuttle run performance. Journal of Physical Activity and Health, 3(Suppl. 2), 34-46.

Marcus, B. H., \& Forsyth, L. H. (2009). Psychologie aktivního způsobu života (L. Dobrý \& J. Hend1, Trans.) (2 ed.). Praha: Portál.

Plowman, S. A., Sterling, C. L., Corbin, C. B., Meredith, M. D., Welk, G. J., \& Morrow, J. J. R. (2006). The history of FITNESSGRAM. Journal of Physical Activity and Health, 3, 5-20.
Seliger, V., \& Bartůněk, Z. (1978). Mean values of various indices of physical fitness in the investigation of Czech population aged 12-55 years. Praha: Olympia.

Suchomel, A. (2003). Současné př́istupy k hodnocení tělesné zdatnosti u dětí a mládeže (Fitnessgram). Česká kinantropologie, 7(1), 81-98.

Suchomel, A. (2004). Hodnocení tělesné zdatnosti ve školní tělesné výchově. Tělesná výchova a sport mládeže, 70(4), 2-7.

The President's Council on Physical Fitness and Sports. (2010). Definitions: Health, fitness, and physical activity. Retrieved 21. 3. 2011 from the World Wide Web: http://www.fitness.gov/digest_mar2000.htm

Thomas, J. R., Nelson, J. K., \& Silverman, S. J. (2005). Research methods in physical activity (5 ed.). Champaign, IL: Human Kinetics.

Vanhees, L., Lefevre, J., Philippaerts, R., Martens, M., Huygens, W., Troosters, T., et al. (2005). How to assess physical activity? How to assess physical fitness? European Journal of Cardiovascular Prevention and Rehabilitation, 12(2), 102-114.

Welk, G. J., \& Meredith, M. D. (Eds.). (2008). FITNESSGRAM/ACTIVITYGRAM: Reference Guide (3 ed.). Dalas, TX: The Cooper Institute.

WHO. (2010). Diet and physical activity: A public health priority. Retrieved 24. 2. 2010 from the World Wide Web: http://www.who.int/dietphysicalactivity/en/ index.html

\section{JACÍKŮV TEST - NOVÝ POHLED NA KVALITU TESTU \\ (Souhrn anglického textu)}

VÝCHODISKA: Sebehodnocení tělesné zdatnosti vyžaduje hledat motorické testy, které nekladou vysoké materiální, prostorové ani dovednostní nároky na jejich provedení. Jacíkův test (JT) se v tomto ohledu jeví jako velice výhodný. Dosavadní poznatky o vlastnostech tohoto testu však nejsou úplné. Vzhledem k pohybové náplni JT lze předpokládat, že výkon v tomto testu bude do určité míry podmíněn také úrovní aerobní zdatnosti.

CÍLE: Cílem studie je posoudit reliabilitu JT a stanovit podíl aerobní zdatnosti na testovém výkonu.

METODY: Výzkumný soubor tvoří dvě samostatné skupiny vysokoškoláků - 43 žen (stanovení validity testu; $22,2 \pm 2,0$ let; $\mathrm{BMI}=23.2 \pm 2.5 \mathrm{~kg} / \mathrm{m}^{2}$; výkonnost $\mathrm{v} \mathrm{JT}=79.1 \pm 9.2$ bodů; $\mathrm{VO}_{2} \max =44.6 \pm 4.7 \mathrm{ml} / \mathrm{kg} / \mathrm{min}$.) a 41 mužů (stanovení reliability testu; 21,5 $\pm 1,2$ let; $\mathrm{BMI}=25.2 \pm 1.6 \mathrm{~kg} / \mathrm{m}^{2}$; výkonnost $\mathrm{v} \mathrm{JT}=83.9 \pm 8.2$ bodů při prvním, resp. $87.5 \pm 9.1$ bodů při druhém pokusu). Podíl aerobní zdatnosti na výkonu v JT je vyjádřena mírou asociace mezi výkonem $\mathrm{v} \mathrm{JT}$ a odhadem $\mathrm{VO}_{2} \max$ (stanoveno využitím Maximálního zátěžového testu na 
běhátku). Objektivita a míra relativní reliability je vyjádřena pomocí ICC. SEM a Bland-Altmanovy 95\% limity shody byly stanoveny k posouzení absolutní reliability.

VÝSLEDKY: Byl zjištěn nízký podíl společné variability $\mathrm{JT}$ a $\mathrm{VO}_{2} \max$ (pouhých 13,3\%). $\mathrm{ICC}_{\text {inter-raters }}=$ 0,997 ukazuje na vysokou míru objektivity (inter-rater reliability). Výsledek $\mathrm{ICC}_{\text {inter-trials }}=0,790$ naznačuje „pochybnou úroveñ “ relativní reliability. Systematická chyba měření dosahuje hodnoty 3,54 bodu. Na neuspokojivou míru absolutní reliability ukazuje jak SEM = 3,96 bodu, tak i šiře Bland-Altmanových $95 \%$ limitů shody $(-9,2$; 16,3).

ZÁVĚRY: JT není vhodný nástroj pro hodnocení motorických předpokladů u vysokoškoláků, a to především z důvodů nízké reliability (relativní i absolutní). Interpretace výsledkủ tohoto testu by byla zavádějící.

Klícová slova: reliabilita, sebehodnocení, studenti, testy motorické, validita, $\mathrm{VO}_{2}$ max.

\section{Mgr. Roman Cuberek, Ph.D.}

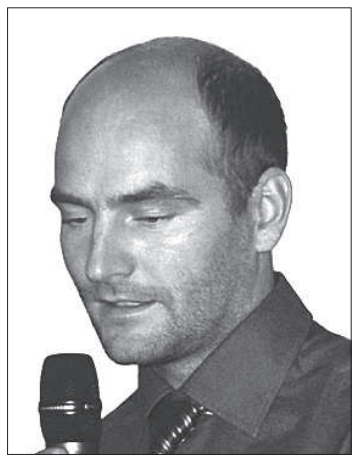

Palacký University, Olomouc Faculty of Physical Culture tř. Míru 115

77111 Olomouc

Czech Republic

\section{Education and previous work experience}

2000-2007 - Ph.D. study program at the Faculty of Physical Culture, Palacký University, Olomouc.

\section{First-line publications}

Cuberek, R., \& Frömel, K. (2011). K problematice výzkumného výběru a testování nulové hypotézy. Československá psychologie, 55(5), 468-477.

Cuberek, R., \& Machová, I. (2009). The motor performance progression of future undergraduate students of physical education. Acta Universitatis Palackianae Olomucensis. Gymnica., 39(4), 15-23.

Cuberek, R., Ansari, W. E., Frömel, K., Skalik, K., \& Sigmund, E. (2010). A comparison of two motion sensors for the assessment of free-living physical activity of adolescents. International Journal of Environmental Research and Public Health, 7(4), 1558-1576.

Cuberek, R., Skalik, K., \& Frömel, K. (2009). Komparace individuální kategorizace úrovně pohybové aktivity monitorované akcelerometrem a krokoměrem. Česká kinantropologie, 13(4), 9-15.

Kokštejn, J., Psotta, R., Frömel, K., Frýbort, P., Jahodová, G., \& Cuberek, R. (2011). Pohybová aktivita dětí s motorickým deficitem. Česká kinantropologie, 15(3), 76-88. 